\title{
Multi-Criteria Decision Making and its Applications
}

\author{
Shweta Panjwani, S Naresh Kumar, Laxmi Ahuja
}

\begin{abstract}
Multi-criteria decision making (MCDM) is a powerful operational model which are used to resolve decision making problems on the basis of different decision criteria. This approach has been widely used in many application fields by the decision makers to solve their problems. Although there exists different MCDM methods but the basic principle of MCDM method involves selection of criteria, selection of alternatives, selection of aggregation methods and weight criteria using these methods and finally evaluation of a set of alternatives performed based on criteria weights. This study presents a small description on the working principle and different methods of a Multi-criteria decision making and furthermore provides survey on their application in different fields.
\end{abstract}

Index Terms: Alternatives, Criteria, Multi-criteria decision making (MCDM), TOPSIS.

\section{INTRODUCTION}

Multi criteria decision making becomes an important operational research part, which supports the decision makers with structuring and resolving decision making problems. Multi criteria decision making (MCDM) is an approach of selecting the perfect alternative among all the possible alternatives on the basis of different decision criteria (Ișılar et al. 2007). MCDM process works on the common principle which are

- Selection of the criteria which should be coherent with the decision and independent of each other.

- Selection of the alternatives which should be available and comparable.

- Selection of the Weighing and Aggregation methods.

Decision making based on the Aggregated results.

\section{MCDM METHODS CLASSIFICATION}

There are many ways using which MCDM methods can be classified. One way of classification is based on the number of the decision makers i.e. single decision making and group decision making methods. MCDM methods can also be distinguished according to the information used and feature of this information (Chen and Hwang, 1992). Some of the most commonly used method are discussed here.

The weighted sum model (or WSM) is the commonly used simple MCDM method, especially for single dimensional problems. The best alternative from $\mathrm{M}$ alternatives and $\mathrm{N}$ criteria can be evaluated using following equation (Fishburn,1971)

Revised Manuscript Received on July 10, 2019.

Shweta Panjwani, CESCRA, Indian Agricultural Research Institute, New Delhi, India.

S Naresh Kumar, CESCRA, Indian Agricultural Research Institute, New Delhi, India.

Laxmi Ahuja, AIIT, Amity University, New Delhi, India.

$$
A w s m_{i}=\operatorname{Max} \sum_{j=1}^{n} w_{i} a_{i j}
$$

The weight product model (or WPM) is analogues to the weighted sum model but the only difference is that the best alternative can be evaluated by comparing the ratio of the corresponding criterion using the following equation (Bridgman,1922 and Triantaphyllou,2000).

$$
P\left(A^{A_{k}} / A_{\mathbb{l}}\right)=\prod_{j=1}^{n}\left({ }^{a_{K j}} / a_{L j}\right)^{w_{j}}
$$

The Elimination and Choice Translating Reality (ELECTRE) method was developed by Bernard Roy,1991 at SEMA company. This method uses the working principle of outranking approach and creates the pairwise comparison matrix among the alternatives corresponding to each criterion and make the "outranking relations" using these matrices. The outranking relationship of $A_{i}$ with $A_{j}$ describes the event when the $i^{\text {th }}$ alternative does not perform better than the $j^{\text {th }}$ alternative quantitatively, then the decision maker may ignore $A_{j}$ and can consider $A_{i}$ as better than $A_{j}$. Finally, it produces the leading alternatives after eliminating the less favorable alternatives. A Preference Ranking Organisation Method (PROMETHEE) is another MCDM technique which uses the concept of outranking approach (Brans \& Vincke,1985).

The Technique for Order of Preference by Similarity to Ideal Solution (TOPSIS), developed by Hwang and Yoon, is an alternative decision-making method of ELECTRE method. The basic concept used by this method is that the feasible selected alternative possesses the minimum distance from the ideal solution and the maximum distance from the negative-ideal solution. This method usually makes an assumption that each criterion has monotonically increasing or decreasing tendency, which becomes easy to locate the positive or negative ideal solutions (Hwang \& Yoon,1981). The Euclidean distance method is then used to measure the distances of each alternative which sets the preference order for each alternative.

The Analytical Hierarchy Process (AHP) is an another MCDM method which was developed by Saaty and this method decomposes complex problem into small hierarchies of attributes and alternatives. AHP mainly uses the concept of the priority-based theory.

The relative priority or weight of alternatives with respect to the criterion is evaluated in the form of M X N matrix. This method works with relative values rather than actual values; hence it is used in the single as well as multi-dimensional decision problems. Fuzzy AHP is an advanced version

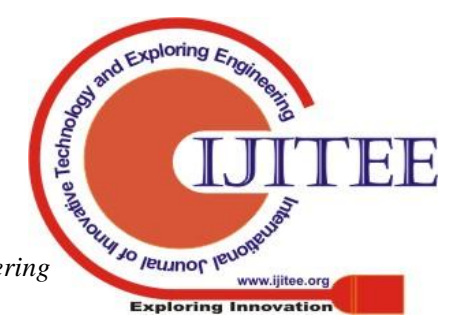


of AHP model, which uses the concept of fuzzy theory along with hierarchal structure analysis to solve decision making problem. Initially the fuzzy numbers with triangular membership functions was used to describe the fuzzy comparing judgment (Van Laarhoven and Pedrycz ,1983) but later on the fuzzy priorities of comparison ratios with trapezoidal membership functions was used. Chang (1996) proposed a new method which works using the extent analysis method for the pairwise comparison scale of AHP and the synthetic extent values of the pairwise comparisons, respectively along with the triangular fuzzy numbers.

TABLE I. MULTI-CRITERIA DECISION MAKING METHODS AND ITS MERITS AND DEMERITS

\begin{tabular}{|c|c|c|c|c|}
\hline No. & $\begin{array}{l}\text { MCDM } \\
\text { Methods }\end{array}$ & Description & Advantages & Disadvantages \\
\hline 1. & $\begin{array}{l}\text { Weighted } \\
\text { Sum } \\
\text { Model } \\
\text { (WSM) }\end{array}$ & $\begin{array}{l}\text { It is used for } \\
\text { evaluating a } \\
\text { number of } \\
\text { alternatives } \\
\text { in } \\
\text { accordance } \\
\text { to the } \\
\text { different } \\
\text { criteria } \\
\text { which are } \\
\text { expressed in } \\
\text { the same } \\
\text { unit. }\end{array}$ & $\begin{array}{l}\text { Strong in a } \\
\text { single } \\
\text { dimensional } \\
\text { problem }\end{array}$ & $\begin{array}{l}\text { Less flexible } \\
\text { with } \\
\text { multi-dimensi } \\
\text { onal problems }\end{array}$ \\
\hline 2. & $\begin{array}{l}\text { Weighted } \\
\text { Product } \\
\text { model } \\
(\mathrm{WPM})\end{array}$ & $\begin{array}{l}\text { Alternatives } \\
\text { are being } \\
\text { compared } \\
\text { with the } \\
\text { other by the } \\
\text { weights and } \\
\text { ratio of one } \\
\text { for each } \\
\text { criterion. }\end{array}$ & $\begin{array}{l}\text { Relative } \\
\text { values are } \\
\text { used rather } \\
\text { than actual } \\
\text { ones. }\end{array}$ & $\begin{array}{l}\text { No solution } \\
\text { for DMs with } \\
\text { equal weight }\end{array}$ \\
\hline 3. & $\begin{array}{l}\text { ELECTR } \\
\text { E/ } \\
\text { PROMET } \\
\text { HEE }\end{array}$ & $\begin{array}{l}\text { It is used to } \\
\text { select the } \\
\text { more } \\
\text { favourable } \\
\text { and less } \\
\text { conflict } \\
\text { alternative } \\
\text { in various } \\
\text { criteria }\end{array}$ & $\begin{array}{l}\text { Outranking } \\
\text { is used }\end{array}$ & $\begin{array}{l}\text { Time } \\
\text { consuming }\end{array}$ \\
\hline 4. & TOPSIS & $\begin{array}{l}\text { It aggregates } \\
\text { and } \\
\text { represents } \\
\text { decision } \\
\text { close to an } \\
\text { ideal } \\
\text { solution. }\end{array}$ & $\begin{array}{l}\text { Gives best } \\
\text { optimal } \\
\text { solution. }\end{array}$ & Less flexible \\
\hline 5. & $\begin{array}{l}\text { Analytic } \\
\text { hierarchy } \\
\text { process } \\
\text { (AHP) }\end{array}$ & $\begin{array}{l}\text { It also } \\
\text { includes pair } \\
\text { wise } \\
\text { comparison } \\
\text { of different } \\
\text { alternatives } \\
\text { for different } \\
\text { criterion. }\end{array}$ & $\begin{array}{l}\text { 1.Flexible } \\
\text { and intuitive } \\
2 . \quad \text { Since } \\
\text { problem is } \\
\text { constructed } \\
\text { into a } \\
\text { hierarchical } \\
\text { structure, } \\
\text { the } \\
\text { importance } \\
\text { of each } \\
\text { element }\end{array}$ & $\begin{array}{l}1 . \\
\text { Irregularities } \\
\text { in ranking } \\
2 . \quad \text { More } \\
\text { number of pair } \\
\text { wise } \\
\text { comparisons } \\
\text { are needed }\end{array}$ \\
\hline
\end{tabular}

MCDM methods are found applicable in evaluating and managing the real-world problems in various sectors. Some of the MCDM methods applications are discussed in this section. In Industry, MCDM has number of applications which includes the decision analysis in manufacturing (Chakraborty et al.,2014), to resolve the decisions problems related to the technology investment (Boucher and McStravic, 1991). Fuzzy AHP is also used for industrial automation e.g. Development of fuzzy logic-based PLC's like Moeller which can be used to restrict or manage the industrial processes.

Fuzzy MCDM plays an important role in the banking applications, especially in the performance evaluation of bank (Tzeng \& Chen,2009), which can help creditors or investors to determine the bank's capabilities. Fuzzy TOPSIS method found useful to develop credit limit allocation model for different regions.

MCDM techniques combines with the GIS are useful in the landslide susceptibility mapping, evaluation of land use suitability and allocation (Pereira,1993) and in the estimation of the proper placement of photovoltaic solar power plants (Uyan,2013).

MCDM has a large number of applications related to the renewable energy issues i.e. in the planning and evaluation of renewable energy policy, project selection and allocation etc (Taha \& Daim,2013).

In agriculture, Multi criteria decision analysis are useful in production analysis for irrigated farms, agricultural resource management and risks aversion. The MCDM technique along with Analytical network process developed a DEMATEL model that can be used to analyze the agricultural land suitability depending on the different criteria like temperature, wind, soil, water etc. (Pourkhabbaz et al.,2013). MCDM methods like TOPSIS, VIKOR, AHP along with fuzzy logic are found useful in the assessment the performance of health care services (Karadayi et al.,2014). Some infectious waste is generated in healthcare facilities; it should be disposed in proper manner.

To select an optimal waste dispose firm from different alternatives, multi criteria decision making grey theory-based model was used (Thakur et al. ,2015).

MCDM methods also plays an important role applicable in other fields i.e. in the Education sector for the evaluation of teacher's performance for appraisal, student's evaluation, in the selection of supervisor, to rank the Universities $(\mathrm{Wu}, \mathrm{H}$. Y. et al., 2012), in the Construction management for the investors, to analyze the construction risks, in the public office building for 
selection of tenders related to designing and planning (P\&D) (Hsieh et al., 2004), in the road and airline safety management and several other fields.

\begin{tabular}{|c|c|c|c|}
\hline $\begin{array}{l}\text { Sl. } \\
\text { No }\end{array}$ & $\begin{array}{l}\text { MCDM } \\
\text { Technique }\end{array}$ & Application Area & Reference \\
\hline 1 & ELECTRE & $\begin{array}{l}\text { Selection of solid waste } \\
\text { management system }\end{array}$ & $\begin{array}{l}\text { Hokkanen et al } \\
1995\end{array}$ \\
\hline 2 & & Energy Planning & $\begin{array}{l}\text { Beccali et al. } \\
1998\end{array}$ \\
\hline 3 & & $\begin{array}{l}\text { Selection of route for } \\
\text { Dublin port motorway }\end{array}$ & $\begin{array}{l}\text { Rogers \& } \\
\text { Bruen,2000 } \\
\end{array}$ \\
\hline 4 & & $\begin{array}{l}\text { Water supply system } \\
\text { decision }\end{array}$ & $\begin{array}{l}\text { Morais et al. } \\
2006\end{array}$ \\
\hline 5 & & $\begin{array}{l}\text { Improving house } \\
\text { design performance }\end{array}$ & $\begin{array}{l}\text { Oltean-Dumbra } \\
\text { va }, 2006\end{array}$ \\
\hline 6 & & $\begin{array}{l}\text { Requirement } \\
\text { prioritization }\end{array}$ & $\begin{array}{l}\text { Mary et al. } \\
2016\end{array}$ \\
\hline 7 & $\begin{array}{l}\text { PROMETHE } \\
\text { E }\end{array}$ & $\begin{array}{l}\text { Evaluation of } \\
\text { international banking } \\
\text { sector }\end{array}$ & $\begin{array}{l}\text { Mareschal \& } \\
\text { Mertens, } 1992\end{array}$ \\
\hline 8 & & $\begin{array}{l}\text { Water resources } \\
\text { planning }\end{array}$ & $\begin{array}{l}\text { Abu-Taleb \& } \\
\text { Mareschal,199 } \\
5\end{array}$ \\
\hline 9 & & $\begin{array}{lr}\text { RANKING } & \text { OF } \\
\text { ALTERNATIVE } & \text { ENERGY } \\
\text { EXPLOITATION PROJECTS }\end{array}$ & $\begin{array}{l}\text { Goumas \& } \\
\text { Lygerou,2000 }\end{array}$ \\
\hline 10 & & Equipment selection & $\begin{array}{l}\text { Dağdeviren,20 } \\
08\end{array}$ \\
\hline 11 & TOPSIS & $\begin{array}{l}\text { Inter-Company } \\
\text { comparison }\end{array}$ & Deng et al.2000 \\
\hline 12 & & $\begin{array}{l}\text { Assessment building } \\
\text { requirement analysis }\end{array}$ & Li et al. 2011 \\
\hline 13 & & $\begin{array}{l}\text { Ranking of General } \\
\text { circulation models }\end{array}$ & Raju et al. 2015 \\
\hline 14 & $\begin{array}{l}\text { Fuzzy } \\
\text { TOPSIS }\end{array}$ & $\begin{array}{l}\text { Company Plant } \\
\text { location selection }\end{array}$ & Yong,2006 \\
\hline 15 & & Supplier selection & $\begin{array}{l}\text { Boran et al. } \\
2009\end{array}$ \\
\hline 16 & $\begin{array}{l}\text { Analytic } \\
\text { hierarchy } \\
\text { Process } \\
\text { (AHP) } \\
\end{array}$ & Supplier Selection & $\begin{array}{l}\text { Nydick \& Hill } \\
\text {,1992 }\end{array}$ \\
\hline 17 & & Contractor Selection & $\begin{array}{l}\text { Fong et } \\
\text { al.,2000 }\end{array}$ \\
\hline 18 & & $\begin{array}{l}\text { Environment } \\
\text { management plan }\end{array}$ & $\begin{array}{l}\text { Ramanathan,20 } \\
01\end{array}$ \\
\hline 19 & & $\begin{array}{l}\text { Project Management } \\
\text { evaluation }\end{array}$ & Al-Harbi, 2001 \\
\hline 20 & & $\begin{array}{l}\text { Prioritize resource } \\
\text { allocation }\end{array}$ & $\begin{array}{l}\text { Cheng \& Li } \\
, 2001\end{array}$ \\
\hline 21 & & $\begin{array}{l}\text { Selection of project } \\
\text { delivery method }\end{array}$ & $\begin{array}{l}\text { Mahdi \& } \\
\text { Alreshaid,2005 }\end{array}$ \\
\hline 22 & & $\begin{array}{l}\text { Evaluation of } \\
\text { Information and } \\
\text { Communication } \\
\text { Technology (ICT) } \\
\text { network system in } \\
\text { health services }\end{array}$ & $\begin{array}{l}\text { Oddershede et } \\
\text { al. } 2008\end{array}$ \\
\hline 23 & & $\begin{array}{l}\text { Selection of Solar site } \\
\text { firms }\end{array}$ & Uyan,2013 \\
\hline 24 & $\begin{array}{l}\text { Analytic } \\
\text { hierarchy } \\
\text { Process } \\
\text { (AHP) with } \\
\text { SWOT } \\
\text { Analysis }\end{array}$ & Forest-certification & $\begin{array}{l}\text { Kurttila et } \\
\text { al.,2000 }\end{array}$ \\
\hline
\end{tabular}

\begin{tabular}{|c|c|c|c|}
\hline 25 & Fuzzy AHP & $\begin{array}{l}\text { Modular product } \\
\text { design }\end{array}$ & Lee et al. 2001 \\
\hline 26 & & $\begin{array}{l}\text { Program aspect } \\
\text { assessment }\end{array}$ & $\begin{array}{l}\text { Belton \& } \\
\text { Stewart, } 2002 .\end{array}$ \\
\hline 27 & & $\begin{array}{l}\text { Determine the optimum } \\
\text { spatial allocation }\end{array}$ & $\begin{array}{l}\text { Wu,Lee \& Lin, } \\
2004\end{array}$ \\
\hline 28 & & Capital Investment & $\begin{array}{l}\text { Tang et al., } \\
2005\end{array}$ \\
\hline 29 & & $\begin{array}{l}\text { Operating system } \\
\text { selection }\end{array}$ & $\begin{array}{l}\text { Tolga et al. } \\
, 2005\end{array}$ \\
\hline 30 & & $\begin{array}{l}\text { Risk based } \\
\text { environmental decision } \\
\text { making }\end{array}$ & $\begin{array}{l}\text { Tesfamariam \& } \\
\text { Sadiq,2006 }\end{array}$ \\
\hline 31 & & $\begin{array}{l}\text { Prirotization of } \\
\text { strategies for reuse of } \\
\text { treated waste water }\end{array}$ & $\begin{array}{l}\text { Khoram et al. } \\
2007\end{array}$ \\
\hline 32 & & $\begin{array}{l}\text { Assessment of water } \\
\text { management plans }\end{array}$ & $\begin{array}{l}\text { Srdjevic \& } \\
\text { Medeiros,2008 }\end{array}$ \\
\hline 33 & & $\begin{array}{l}\text { Evaluation of energy } \\
\text { sources }\end{array}$ & Meixner,2009 \\
\hline 34 & & $\begin{array}{l}\text { Evaluation and } \\
\text { selection of product of } \\
\text { computers }\end{array}$ & $\begin{array}{l}\text { Srichetta et al., } \\
2012\end{array}$ \\
\hline 35 & & $\begin{array}{l}\text { Supplier selection } \\
\text { problem }\end{array}$ & Ayhan ,2013 \\
\hline 36 & & Plant Species Selection & Alavi,2014 \\
\hline 37 & & $\begin{array}{l}\text { Evaluating teaching } \\
\text { performance }\end{array}$ & $\begin{array}{l}\text { Chen et al. } \\
2015\end{array}$ \\
\hline 38 & & $\begin{array}{l}\text { Ship energy efficiency } \\
\text { management plan }\end{array}$ & $\begin{array}{l}\text { Beşikçi et al. } \\
\text {,2016 }\end{array}$ \\
\hline 39 & & Industrial site selection & $\begin{array}{l}\text { Taibi \& } \\
\text { Atmani,2017 }\end{array}$ \\
\hline 40 & & $\begin{array}{l}\text { Measuring healthcare } \\
\text { services }\end{array}$ & $\begin{array}{l}\text { Singh \& } \\
\text { Prasher ,2019 } \\
\end{array}$ \\
\hline 41 & MCDM & $\begin{array}{l}\text { Software defect } \\
\text { detection algorithms } \\
\text { selection }\end{array}$ & $\begin{array}{l}\text { Peng et al. } \\
2010\end{array}$ \\
\hline 42 & $\begin{array}{l}\text { Fuzzy AHP } \\
\text { with Fuzzy } \\
\text { TOPSIS }\end{array}$ & $\begin{array}{l}\text { Water Loss } \\
\text { Management }\end{array}$ & $\begin{array}{l}\text { Zyoud et } \\
\text { al.,2016 }\end{array}$ \\
\hline 43 & $\begin{array}{l}\text { SAW,TOPSI } \\
\text { S,Fuzzy } \\
\text { TOPSIS }\end{array}$ & $\begin{array}{l}\text { Cultivation priority } \\
\text { planning for maize, } \\
\text { rapeseed and soybean } \\
\text { crops }\end{array}$ & $\begin{array}{l}\text { Seyedmohamm } \\
\text { adi et al.,2018 }\end{array}$ \\
\hline
\end{tabular}

Initially, MCDM techniques ELECTRE, PROMETHEE, TOPSIS, AHP were used in different application areas like supplier selection, resources planning etc., now a day these techniques are embedded with Fuzzy sets to reduce the uncertainties in different application areas (Table 2). Instead of using single technique, combination of different(hybrid) techniques can be used for various applications which may produce better results.

\section{CONCLUSION}

Many MCDM methods like AHP, TOPSIS, ELECTRE are available which are helpful to resolve

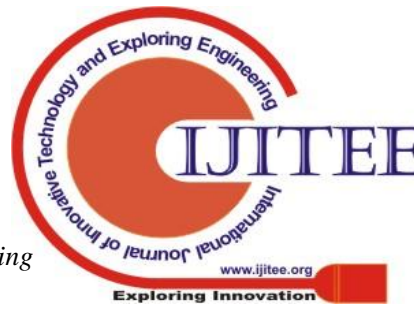




\section{Multi-Criteria Decision Making and its Applications}

the decision-making problems. The basic concept of all the methods remains same, only the weight determination concept differs. These methods have different applications in different fields like Energy, GIS, Agriculture, Industry, Construction and other sectors. An appropriate approach has been selected according to the problem and its domain.

\section{REFERENCES}

[1] Işsklar, G., \&Büyüközkan, G. (2007). Using a multi-criteria decision making approach to evaluate mobile phone alternatives. Computer Standards \& Interfaces, 29(2), 265-274.

[2] Chen, S. J., \& Hwang, C. L. (1992). Fuzzy multiple attribute decision making methods. In Fuzzy Multiple Attribute Decision Making (pp. 289-486). Springer Berlin Heidelberg.

[3] Fishburn, P. C. (1971). Additive representations of real-valued functions on subsets of product sets. Journal of Mathematical Psychology, 8(3), 382-388.

[4] Bridgman, P. W. (1922). Dimensional analysis. Yale University Press.

[5] Triantaphyllou, E. (2000). Multi-Criteria Decision Making: A Comparative Study. Dordrecht, The Netherlands: Kluwer Academic Publishers (now Springer). p. 320.

[6] Brans, J. P., \& Vincke, P. (1985). Note-A Preference Ranking Organisation Method: (The PROMETHEE Method for Multiple Criteria Decision-Making). Management science, 31(6), 647-656.

[7] Roy, B. (1991). The outranking approach and the foundations of ELECTRE methods. Theory and decision, 31(1), 49-73.

[8] Saaty TL (1980) The Analytic Hierarchy Process. McGraw-Hill, New York.

[9] Hwang, C.L.; Yoon, K. (1981). Multiple Attribute Decision Making: Methods and Applications. New York: Springer-Verlag .

[10] Van Laarhoven, P. J. M., \& Pedrycz, W. (1983). A fuzzy extension of Saaty's priority theory. Fuzzy sets and Systems, 11(1-3), 229-241.

[11] Chang, D. Y. (1996). Applications of the extent analysis method on fuzzy AHP. European journal of operational research,95(3), 649-655.

[12] Chakraborty, S., \& Zavadskas, E. K. (2014). Applications of WASPAS method in manufacturing decision making. Informatica, 25(1), 1-20.

[13] Boucher, T. O., \& MacStravic, E. L. (1991). Multi attribute evaluation within a present value framework and its relation to the analytic hierarchy process. The Engineering Economist, 37(1), 1-32.

[14] Taha, R. A., \& Daim, T. (2013). Multi-criteria applications in renewable energy analysis, a literature review. In Research and Technology Management in the Electricity Industry (pp. 17-30). Springer London.

[15] Pourkhabbaz, H., Javanmardi, S., Yavari, A. R., \& Sabokbar, H. F. (2013). Application of Multi Criteria Decision Making Method and the Integrated ANP-DEMATEL Model for Agricultural Land Suitability Analysis (Case study: Qazvin Plain). Journal of Environmental Studies, 39(3), 35.

[16] Karadayi, M. A., \& Karsak, E. E. (2014). Fuzzy MCDM Approach for Health-Care Performance Assessment in Istanbul.

[17] Thakur, V., \& Ramesh, A. (2015). Selection of waste disposal firms using grey theory based multi-criteria decision making technique. Procedia-Social and Behavioral Sciences, 189, 81-90.

[18] Hokkanen, J., Salminen, P., Rossi, E., \& Ettala, M. (1995). The choice of a solid waste management system using the ELECTRE II decision-aid method. Waste Management \& Research, 13(2), 175-193.

[19] Wu, H. Y., Chen, J. K., Chen, I. S., \& Zhuo, H. H. (2012). Ranking universities based on performance evaluation by a hybrid MCDM model. Measurement, 45(5), 856-880.

[20] Hsieh, T. Y., Lu, S. T., \& Tzeng, G. H. (2004). Fuzzy MCDM approach buildings. International journal of project management, 22(7), 573-584.

[21] Beccali, M., Cellura, M., \& Ardente, D. (1998). Decision making in energy planning: the ELECTRE multicriteria analysis approach compared to a fuzzy-sets methodology. Energy Conversion and Management, 39(16-18), 1869-1881.

[22] Rogers, M., \& Bruen, M. (2000). Using ELECTRE III to choose route for Dublin port motorway. Journal of Transportation Engineering, 126(4), 313-323. for planning and design tenders selection in public office

[23] Morais, D. C., \& Almeida, A. T. (2006). Water supply system decision making using multicriteria analysis. Water Sa, 32(2), 229-236.

[24] Oltean-Dumbrava, C. (2006). Improving housing design performance using ELECTRE III. International Journal for Housing Science and Its Applications, 30(1), 1.

[25] Mary, S.A.S.A. and Suganya, G. (2016) Multi-Criteria Decision Making Using ELECTRE. Circuits and Systems,7,1008-1020.

[26] Mareschal, B., \& Mertens, D. (1992). BANKS a multicriteria, PROMETHEE-based, decision support system for the evaluation of the international banking sector. Journal of Decision Systems, 1(2-3), 175-189.

[27] Abu-Taleb, M. F., \& Mareschal, B. (1995). Water resources planning in the Middle East: application of the PROMETHEE V multicriteria method. European journal of operational research, 81(3), 500-511.

[28] Goumas, M., \& Lygerou, V. (2000). An extension of the PROMETHEE method for decision making in fuzzy environment: Ranking of alternative energy exploitation projects. European Journal of Operational Research, 123(3), 606-613.

[29] Dağdeviren, M. (2008). Decision making in equipment selection: an integrated approach with AHP and PROMETHEE. Journal of intelligent manufacturing, 19(4), 397-406.

[30] Deng, H., Yeh, C. H., \& Willis, R. J. (2000). Inter-company comparison using modified TOPSIS with objective weights. Computers \& Operations Research, 27(10), 963-973.

[31] Li, Y.-M., Lai, C.-Y., \& Kao, C.-P. (2011). Building a qualitative recruitment system via SVM with MCDM approach. Applied Intelligence, 35, 75 .

[32] Raju KS, Kumar DN (2015) Ranking general circulation models for India using TOPSIS. J Water Clim Change 6(2):288-299.

[33] Yong, D. (2006). Plant location selection based on fuzzy TOPSIS. The International Journal of Advanced Manufacturing Technology, 28(7-8), 839-844.

[34] Boran, F. E., Genç, S., Kurt, M., \& Akay, D. (2009). A multi-criteria intuitionistic fuzzy group decision making for supplier selection with TOPSIS method. Expert Systems with Applications, 36(8), 11363-11368.

[35] Nydick, R. L., \& Hill, R. P. (1992). Using the analytic hierarchy process to structure the supplier selection procedure. International Journal of Purchasing and Materials Management, 28(2), 31-36.

[36] Fong, P. S. W., \& Choi, S. K. Y. (2000). Final contractor selection using the analytical hierarchy process. Construction management and economics, 18(5), 547-557.

[37] Ramanathan, R. (2001). A note on the use of the analytic hierarchy process for environmental impact assessment. Journal of environmental management, 63(1), 27-35.

[38] Al-Harbi, K. M. (2001). Application of the AHP in project management. International Journal of Project Management, 19, 19 -27 .

[39] Cheng, E. W., \& Li, H. (2001). Information priority-setting for better resource allocation using analytic hierarchy process (AHP). Information Management \& Computer Security, 9(2), 61-70.

[40] Oddershede Herrera, A., Carrasco González, R., \& Abu-Muhor, E. B. (2008). Multi-criteria Decision Model for Assessing Health Service Information Technology Network Support Using the Analytic Hierarchy Process. Computación y Sistemas, 12(2), 173-182.

[41] Pereira, J. M., \& Duckstein, L. (1993). A multiple criteria decision-making approach to GIS-based land suitability evaluation. International Journal of Geographical Information Science, 7(5), 407-424.

[42] Uyan, M. (2013). GIS-based solar farms site selection using analytic hierarchy process (AHP) in Karapinar region, Konya/Turkey. Renewable and Sustainable Energy Reviews, 28, 11-17.

[43] Kurttila, M., Pesonen, M., Kangas, J., \& Kajanus, M. (2000). Utilizing the analytic hierarchy process (AHP) in SWOT analysis - a hybric method and its application to a forest-certification case. Forest policy and economics, 1(1), 41-52.

[44] Lee, W. B., Lau, H., Liu, Z. Z., \& Tam, S. (2001). A fuzzy analytic hierarchy process 
approach in modular product design. Expert Systems, 18(1), 32-42.

[45] V. Belton and T. Stewart, Multiple criteria decision analysis: an integrated approach. Springer Science \& Business Media, 2002.

[46] Wu, F. G., Lee, Y. J., \& Lin, M. C. (2004). Using the fuzzy analytic hierarchy process on optimum spatial allocation. International Journal of Industrial Ergonomics, 33(6), 553-569.

[47] Tang, Y. C., \& Beynon, M. J. (2005). Application and development of a fuzzy analytic hierarchy process within a capital investment study. Journal of Economics and Management, 1(2), 207-230.

[48] Tolga, E., Demircan, M. L., \& Kahraman, C. (2005). Operating system selection using fuzzy replacement analysis and analytic hierarchy process. International Journal of Production Economics,97(1), 89-117.

[49] Tesfamariam, S., \& Sadiq, R. (2006). Risk-based environmental decision-making using fuzzy analytic hierarchy process (F-AHP). Stochastic Environmental Research and Risk Assessment, 21(1), 35-50.

[50] Khoram, M. R., Shariat, M., Azar, A., Moharamnejad, N., \& Mahjub, H. (2007). Prioritizing the strategies and methods of treated wastewater reusing by fuzzy analytic hierarchy process (FAHP): a case study. International Journal of Agriculture and Biology (Pakistan).

[51] Srdjevic, B., \& Medeiros, Y. D. P. (2008). Fuzzy AHP assessment of water management plans. Water Resources Management, 22(7), 877-894.

[52] Meixner, O. (2009, July). Fuzzy AHP group decision analysis and its application for the evaluation of energy sources. In Proceedings of the 10th International Symposium on the Analytic Hierarchy/Network Process, Pittsburgh, PA, USA (Vol. 29).

[53] Srichetta, P., \& Thurachon, W. (2012). Applying fuzzy analytic hierarchy process to evaluate and select product of notebook computers. International Journal of Modeling and Optimization, 2(2), 168.

[54] Ayhan, M. B. (2013). A fuzzy AHP approach for supplier selection problem: A case study in a Gear motor company. arXiv preprint arXiv:1311.2886.

[55] Alavi, I. (2014). Fuzzy AHP method for plant species selection in mine reclamation plans: case study sungun copper mine. Iranian Journal of Fuzzy Systems, 11(5), 23-38.

[56] Chen, J. F., Hsieh, H. N., \& Do, Q. H. (2015). Evaluating teaching performance based on fuzzy AHP and comprehensive evaluation approach. Applied Soft Computing, 28, 100-108.

[57] Beşikçi, E. B., Kececi, T., Arslan, O., \& Turan, O. (2016). An application of fuzzy-AHP to ship operational energy efficiency measures. Ocean Engineering, 121, 392-402.

[58] Taibi, A., \& Atmani, B. (2017). Combining Fuzzy AHP with GIS and Decision Rules for Industrial Site Selection. International Journal of Interactive Multimedia \& Artificial Intelligence, 4(6).

[59] Singh, A., \& Prasher, A. (2019). Measuring healthcare service quality from patients' perspective: using Fuzzy AHP application. Total Quality Management \& Business Excellence, 30(3-4), 284-300.

[60] Peng Y., Wang G., Wang H., 2010: User preferences based software defect detection algorithms selection using MCDM, Information Sciences, (In press).

[61] Zyoud, S. H., Kaufmann, L. G., Shaheen, H., Samhan, S., \& Fuchs-Hanusch, D. (2016). A framework for water loss management in developing countries under fuzzy environment: Integration of Fuzzy AHP with Fuzzy TOPSIS. Expert Systems with Applications, 61, 86-105.

[62] Seyedmohammadi, J., Sarmadian, F., Jafarzadeh, A. A., Ghorbani, M A., \& Shahbazi, F. (2018). Application of SAW, TOPSIS and fuzzy TOPSIS models in cultivation priority planning for maize, rapeseed and soybean crops. Geoderma, 310, 178-190.

\section{AUTHORS PROFILE}

Shweta Panjwani did her B Sc (Computer Science) and M Sc(IT) from Mohan Lal Sukhadiya University, Rajasthan. She has published various papers in international journal and conferences. Her area of interest is data mining, software languages etc.

Dr S Naresh Kumar, FISPP, FISPC presently working as Professor and Principal Scientist in Indian Agricultural Research Institute, New Delhi. His research area is Climate Change and Crop and Environment Simulation Modelling.He is Member of Steering Council (2018-2020), Agricultural Model Intercomparison and Improvement Programme
(AgMIP), NASA, GISS, Columbia University, USA. He has published various research papers in good international journals like Nature etc.

Dr Laxmi Ahuja : Presently Professor and Dy. Director in Amity Institute of Information Technology, Amity University. Having experience of 19 years in academics; Her areas of interest include Search Engine, Data Mining and Soft Computing Techniques; published more than 50 research papers in (SCI/SCIE/SCOPUS and others) International and National Journals and Conferences including Inderscience, Springer, IEEE, Elseveir ,IGI Global and several others. She is actively involved in research activities. She has currently eight research scholar under her guidance. She is Life Member of Computer Society of India (CSI) ,Past Vice chairman of IETE -The Institute of Electronics and Telecommunications Engineers, Senior member of IACSIT and is actively involved in various activities of these societies, she is also member of IEEE .She is a Member of Technical Programme Committee (TPC) in various conferences across globe. 